\title{
The General Agreement on Trade in Services (GATS) and Poor People's Right to Water
}

\section{Lyla Mehta and Birgit la Cour Madsen*}

\section{Introduction}

During the Uruguay Round the scope of multilateral negotiations under the auspices of the World Trade Organization (WTO) was extended to include trade in services. The outcome was the General Agreement on Trade in Services (GATS), which was established on 1 January 1995. Since 2000, negotiations on the liberalisation of services have been ongoing under the auspices of this agreement. Also known as GATS 2000, these negotiations were initiated in order to strengthen the GATS framework and enhance world trade in services. The result is that WTO member countries are currently negotiating the liberalisation of a wide range of services from education to tourism to rubbish collection and environmental services, which hitherto largely fell under the jurisdiction of state control.

Since the conclusion of the GATS and the launch of GATS 2000, the agreement has come under severe attack by a high-profile worldwide campaign mobilised by organisations such as the World Development Movement and Focus on the Global South in both the North and the South. These organisations and many others have accused the WTO of displaying a severe democratic deficit in the way its agenda has been hijacked by corporate interests, thus having a detrimental impact on the lives and livelihoods of the poor in developing countries. GATS 2000 is seen to be a "frontal attack on the fundamental social rights" enshrined in several UN declarations and accompanying charters and covenants, in particular due to its potential to promote the commodification of life-giving resources such as water and apply market-based mechanisms on sensitive sectors such as health and education. The critics have also raised concerns regarding developing country governments' ability to utilise policy mechanisms that can regulate services in such a way as to achieve universal delivery of basic services and safeguard the interests of poor people.

This article investigates the controversies and processes surrounding efforts to liberalise domestic water-related services under the auspices of the WTO/GATS, with a particular emphasis on the implications for poor people's right to water. It demonstrates that while liberalising water-related services under the GATS may not necessarily undermine, de jure, the ability of member-states to introduce the kind of legislative measures that are necessary to safeguard the interests of the poor, there are a number of reasons to think that, de facto, the exercise of policy autonomy might be substantially curtailed. These constraints on the capacity of member-states to protect the poor stem from (a) inherent ambiguities in treaty interpretation; (b) and the politics of process arising out of power asymmetries and a lack of transparency in processes of negotiation and policy review. These and other factors can potentially lead to conflicting aims and contradictory outcomes around issues of trade, water provision, equity and rights.

The analysis of the GATS and water provision highlights the increasing role of the WTO in defining domestic policy agendas in developing countries in areas that have a direct impact on the poor. The effectiveness with which developing countries can define and negotiate in support of their interests when confronted with the agendas of developed countries and their global service providers will have a substantial impact on the livelihoods of the poorest people in developing countries.

It is important, however, to bear in mind that the analysis presented here is inherently speculative due to the ongoing nature of the negotiations and due to the fact that domestic water service delivery is not officially one of the sectors covered by the 
GATS. No country has so far liberalised its domestic water services under the auspices of the GATS. However, 41 countries have recently offered commitments on wastewater treatment and it is now widely acknowledged that the European Commission (EC) is interested in including water service delivery in the definition of environmental services under GATS, which would clearly serve the interests of European water companies. Thus, the debate around water privatisation, the GATS and poor people's access to water is clearly already a controversial one that warrants discursive, conceptual and empirical analysis. The analysis is conducted both conceptually and empirically on the basis of desk-based research of the growing literature on WTO/GATS negotiations, NGO statements and the general literature on water privatisation experiences and it is complemented by semi-structured interviews with negotiators, campaigners, journalists and bureaucrats

The debates around the GATS and its impact on poor people's access to basic services such as water, are closely related to debates around the nature of water. The article therefore begins by examining the case for the human right to water and the implications that a rights-based view of water has for the provision of water services. It then goes on to explore existing water privatisation experiences and their impact on poor people's access to water. After looking at the controversies around the GATS in more detail, the article then draws on the discussion of existing non-GATS privatisation experiences and their impact on poor people's access to water to investigate whether GATS provisions could undermine a government's freedom to regulate in a manner consistent with equity and social considerations. The article concludes by arguing that such safeguard provisions would exist in an ideal world. However, in practice the politics of process, ambiguity and power at the multilateral and bilateral levels leave many doubts regarding poor people's rights to basic services under GATS.

\section{Is there a fundamental right to water?}

Water is uniquely and fundamentally essential for all aspects of life, well-being and productivity. It is also the lifeblood of ecosystems, essential for many eco-hydrological functions. For poor people, access to clean and affordable water is a prerequisite to achieving a minimum standard of health and to undertake productive activities. However, it is estimated that 1.1 billion people lack access to safe water and almost 2.5 billion people -40 per cent of the world's population - lack access to adequate sanitation (Neto and Tropp 2000: 227).

A growing number of analysts have argued eloquently that access to safe and adequate water is not just a basic need, but a fundamental human right, based on the criteria established in international declarations that protect the right to livelihood and well-being. While the right to water was not explicitly endorsed in the 1948 Universal Declaration of Human Rights (UNDHR), in 2002 a comment by the United Nations Committee on Social and Economic Rights explicitly recognised the right to water as a human right and stressed its importance in realising other human rights (United Nations Economic and Social Council 2002a). It also stressed the role of states in progressively realising the right to water, which is determined to entail the provision of sufficient, safe, affordable water to everyone. There are compelling arguments for viewing access to water as a fundamental right. Significantly improving water and sanitation can reduce the spread of disease and improve people's health and well-being. It can enhance poor households' sense of dignity and independence and free up the one to four hours a day poor women and children spend collecting water. Still, current orthodoxies in the water domain tend to focus on the need to view water as an economic good and there is a marked lack of official endorsement of the human right to water. ${ }^{1}$ Since the Dublin Statement of 1992, ${ }^{2}$ water has increasingly been seen as having economic value in all its competing uses. Because water is scarce, goes the logic, it must be used judiciously and its demand managed. Accordingly, efficient resource management is equated with water having a price.

Access to basic services can either be gained through private contractual arrangements or as entitlements by virtue of citizenship. If 'access to public services is understood as a private contractual right, it is determined by the terms and conditions of the contract between service supplier and consumer' (Krajewski 2002). The defining characteristic of such a contract is the consumer's ability to pay for the service provided by the supplier. In other words, if the right to water is perceived as a contractual rather than a human right, water services are subject to the laws of demand and supply, 
Table 1: Forms of private sector participation in the water sector

Contract type

\begin{tabular}{|c|c|c|c|c|c|c|}
\hline $\begin{array}{l}\text { Private sector } \\
\text { involvement }\end{array}$ & $\begin{array}{l}\text { Service } \\
\text { contract }\end{array}$ & $\begin{array}{l}\text { Management } \\
\text { contract }\end{array}$ & Lease & ВОТ/ВОOа & $\begin{array}{l}\text { Concession } \\
\text { contract }\end{array}$ & Divestiture \\
\hline Asset ownership & Public & Public & Public & $\begin{array}{l}\text { Public and } \\
\text { private }\end{array}$ & Public & $\begin{array}{l}\text { Private or public } \\
\text { and private }\end{array}$ \\
\hline Capital investment & Public & Public & Public & Private & Private & Private \\
\hline Commercial risk & Public & Public & Shared & Private & Private & Private \\
\hline $\begin{array}{l}\text { Operations and } \\
\text { maintenance }\end{array}$ & $\begin{array}{l}\text { Public and } \\
\text { private }\end{array}$ & Private & Private & Private & Private & Private \\
\hline Tariff collection & Public & Public/private & Private & Public & Private & Private \\
\hline Duration & $1-2$ years & $3-5$ years & $8-15$ years & 20-30 years & 25-30 years & $\begin{array}{l}\text { Indefinite (may } \\
\text { be limited by } \\
\text { license) }\end{array}$ \\
\hline
\end{tabular}

Source: Bakker (2002).

which invariably, due to the nature of markets, would be unable to guarantee equality and affordability of access. By contrast when viewed from the human right lens water is a public entitlement, access to which does not depend on one's ability to pay. Nevertheless, viewing the water/trade nexus through a human rights lens does not necessarily mean that water services need to be free of charge or state run. Instead, such a lens implies that states, which involve private actors in the provision of basic services, are legally obliged to establish effective and flexible regulatory mechanisms that can secure the progressive realisation of the right to water for all people. In the current international context, where an increasing number of developing countries are privatising their basic social services, setting up strong mechanisms to regulate private services in order to achieve universal access is of major importance. The key question is, however, whether the regulatory space needed for governments to secure its citizens universal, equal and affordable access to public services is compromised by the principles of the GATS as the activists argue. To answer these questions we need to review non-GATS privatisation experiences as well as the nature and processes around the GATS.

\section{Water privatisation and poor people's rights to water}

The water sector, along with other utilities, has certain specific characteristics, which have clear implications for the way water is managed. First, very few elements of the water sector are naturally competitive, in other words it is characterised by a high level of natural monopoly (Rees 1998). Thus interventions, say in the form of a price ceiling, are required in order to protect consumers from monopoly power abuses (Barr 1998). Second, the water sector is characterised by high capital intensity and the presence of sunk costs, which implies that the investments undertaken in the infrastructure needed to provide a service are neither transferrable or redeployed for other purposes (Rees 1998; Ugaz 2001b). This invariably increases the risk attached to investment in the sector.

Taken together, the above characteristics have often been used to argue for the public provision of water services. In most parts of Europe, public provision has traditionally been considered to be the best way of guaranteeing the principle of universalism, based on its ability to pool risk and make use of cross subsidies to provide low-income households, or those who live in high provision 
cost areas, with affordable services (Finger and Allouche 2002).

Despite maintaining public control, developing countries have often failed to universalise access to water services. This is due to various reasons, which include inadequate financial resources to undertake the investments needed for adequate provision of these services (World Bank 1994; Ugaz 2001a), mismanagement and poor institutional arrangements. Consequently, privatisation has been promoted as the appropriate remedy. Often this has taken place through World Bank and IMF-induced conditionalities. Seen in this light, GATS-driven liberalisation is merely a continuation of liberalisation experiences that developing countries have already encountered, over which they often have not been able to exercise much control.

"Privatisation" refers to "the transfer of majority ownership of state-owned companies (SOEs) to the private sector by the sale of ongoing concerns or of assets following liquidation' (Kikeri et al. 1994: 242). In the water sector, this transfer of ownership takes place in a variety of different ways. As Table 1 shows, there are different ways to organise private involvement in the water sector and each has different characteristics. In the case of a service contract, only the operations and maintenance of water supply are transferred to the private sector, and for periods of typically limited duration. At the other extreme, concession contracts and divestiture transfer most of the activities involving water supply to private companies for long or indefinite periods of time.

Past experience of the last two decades suggests that concession contracts are the most widely adopted privatisation arrangement in the water sector (Nickson 2001). While open competition among competitors in the market is not possible, because of the water sector's status as a natural monopoly, the use of such contracts allow states to create competition for the market (contestability). Thus private utilities are seen to allow market-based mechanisms to discipline the companies and assure higher efficiency levels and investments. Of course, such a situation also creates a parallel opportunity for rent-seeking behaviour on the part of both local politicians and companies (cf. Petrella 2001 and Cecila Ugaz, personal communication, 2002).

Very little research has systematically been conducted on the consequences of privatisation for poor people's access to water and their ability to pay for it. However, the evidence, which is available and publicly accessible, indicates that we have no real reason to be sanguine. Bayliss (2001) reviews the outcome of water privatisation schemes in three African countries: Guinea, Senegal and Côte d'Ivoire. While the nature of the contractual arrangements that govern the involvement of private actors in the three countries' water sectors vary from mediumterm lease contracts to long-term concession contracts, the outcome of the privatisation process is similar across all three cases. Connection rates have increased, sometimes significantly, and clear improvements are documented in core aspects of revenue rising, as a consequence of better tariffs, billing and collection rates. High prices have, however, made public water supplies unaffordable for many of the poorest segments of society, which because of inability to pay have been hit by widespread disconnections. Moreover, it is highly unlikely that the poorest of the poor have benefited from the expansion of network connections, which has taken place in all three countries as a consequence of privatisation. As Rivera (1996) argues, experience shows that the poorest sections of a concession area tend to remain outside the extension perimeter of the privatised services, because they generally are perceived to be a highrisk low return area among private operators of water services. As such, it remains unclear whether and how available privatisation models can be applied in rural areas where people make and sustain livelihoods in a diverse and holistic manner and where reliance on the state, donor agencies and NGOs is also greater (Mehta 2003).

Price increases that place formal water supplies outside the reach of poor people appear to be a frequent outcome of water privatisation. For example, in Manila, 'International Water' - a UK/US consortium - doubled its prices within two years, despite the fact that the initial contract included specified price levels. Likewise, in the highly controversial and now well-known plan to privatise water services in Cochabamba in Bolivia, prices would have increased 35 per cent. So, while it is true, as Nickson (2001) argues that "efficiency" in terms of reduced leakages and improved billing and collection is enhanced in many cases by the involvement of private sector actors in water distribution services, water privatisation is rarely more "efficient" and cost effective in terms of impact on welfare when one considers questions related to access and affordability of water services. The 
changes introduced by the private sector are more likely to be in the interest of profit rather than social development, since there is an inherent conflict between capital markets (which are looking for quick returns) and the need for long-term investment to improve water services in developing countries. As Donnelly argues, markets can lead to compromising social and economic rights since markets 'can systematically deprive some individuals in order to achieve the collective benefits of efficiency' (Donnelly 1999: 628).

Thus, it is essential that all countries have strong regulatory bodies in place prior to privatisation that can subject commercial providers to tariff regulations, quality standards, and sensitivity to welfare concerns which are renegotiable in order to allow for adjustment to changing economic circumstances (Ugaz 2001a; Rees 1998). Still, in practice, apparently neat public administration accountability checks in the form of regulators rarely function in a satisfactory manner. For example, in Buenos Aires, an independent regulatory agency was established to monitor the quality of service, represent consumers and ensure the fair implementation of the contract. However, research demonstrates that at times powerful interests captured it and at times it was too weak to resist them (Loftus and McDonald 2001: 16). Consequently it was ineffective and was not consulted when the contract was rewritten. Thus, regulatory frameworks and institutions may not always work in the interests of the poor. This discussion provides the basis to understand what GATS-led liberalisation would build on.

\section{The controversies around the GATS}

The GATS is the first and only set of multilateral rules covering international trade in services. The agreement covers all services, except those provided in the exercise of governmental authority and those related to air traffic rights (WTO 2002b). ${ }^{3}$ More specifically, the agreement covers four different "modes of supply", which define trade in services under the GATS such as cross-border supply, consumption abroad, commercial presence and presence of natural persons.

The key principle of the GATS, which applies to trade in all service modes, is non-discrimination (WTO 2002b). This implies that all member-states are required to extend most-favoured nation treatment to all other members, i.e. to treat all trading partners equally. This is less onerous than the principle of national treatment. This principle, which requires a country to give the same treatment to others as it does to its own nationals, only applies to those service sectors and modes of supply that are listed in the country's schedule of commitments (WTO 2002b). As the name implies, 'schedules of commitments' list the commitments to open markets in specific sectors made by individual countries. A country can define its schedule so that it can limit not only the degree of national treatment it is willing to accord to foreign competitors but also the level of market access that it is prepared to grant in certain sectors (WTO 2002b). Limiting the degree of national treatment in a certain sector may imply that foreign-service providers are allowed to operate only one branch within the country, while domestic companies face no such restrictions.

The stated aim of the GATS (article 19) is to progressively liberalise trade in services, i.e. open up service sectors that are currently closed to trade and promote the elimination of restrictions considered barriers to trade in sectors that are already open. However, as critics such as Das (2001), writing for Third World Network, argue the focus on 'progressive liberalisation of services' services largely benefits countries, which are endowed with relatively more developed level of services. Indeed, as a group of developing countries argued in 2002, developing countries share of world service exports has increased only by 6 per cent since the adoption of the GATS to 1999. By contrast, OECD (Organization for Economic Cooperation and Development) countries account for three-quarters of world's exports of services and most of these are concentrated in the hands of multinationals. These trends would appear to contradict Article IV of the GATS, which seeks to enhance developing country participation in world trade in services (WTO 2002a).

Critics have also argued that the exemption from the GATS of services provided in the exercise of governmental authority, defined as those services that are supplied: 'neither on a commercial basis, nor in competition with one or more service suppliers' (WTO 2002b: 1), does not necessarily mean that water services and other public services are outside the reach of the GATS. It is unclear whether this exception will apply to public services since the increasing presence of private sector actors in all such sectors in most countries arguably 
constitutes competition to the public sector. As Table 1 shows, there is often a continuum between what constitutes the public and private in service delivery and the separation of what is public and private is rarely clear cut. Similarly, even governments now charge user fees for public services in health and water. It is therefore not clear under what conditions competition would be seen to exist and under what conditions services would qualify under the GATS clause for governmental services. This ambiguity in the agreement can clearly, thus, be manipulated to suit powerful interests and broadly depends on the lens of interpretation. Krajewski (2001), who has discussed the scope of the GATS, concludes that the application of international principles of treaty interpretation to Article 1:3 (b) and (c), which defines the scope of the GATS, is likely to result in a narrow interpretation of what constitutes services provided in the exercise of governmental authority. This consequently means a broad scope of GATS.

Liberalisation under the GATS follows a "requests/offers" process. Countries make requests to other countries to have market access to certain sectors. Subsequently, members respond with offers and commitments. In principle, countries can list conditions and limitation in their schedules regarding the participation of foreign companies in certain sectors and principles to favour domestic firms. Still, as the organisations behind the GATSAttack (GATSwatch 2001) claim, GATS rules may restrict the ability and willingness of governments to commit public funds to public works, municipal services and social programmes because national treatment rules would require such funds to be made available to all actors, public or private, domestic or foreign. It is also argued that the principle of national treatment can limit governments' ability to enact policies that favour the growth of local companies or favour local suppliers and local managers, hire or train local staff (World Development Movement 2002: 21).

According to the supporters of the WTO, the criticisms of GATS are based on misunderstandings and scare stories which negate the fact that the GATS explicitly recognises 'the right of members to regulate, and to introduce new regulations, on the supply of services within their territories in order to meet national policy objectives' (WTO 2002b: 11). We now turn to whether governments would indeed have this right to regulate.

\section{Restrictions on governments' regulatory freedom?}

A key issue regarding poor people's access to water resources under privatised management arrangements concerns whether efforts to achieve universal access will be compromised, especially in rural areas and impoverished urban neighbourhoods. In principle, GATS would allow governments the freedom to develop policies that would support universal access. In fact, there are no restrictions on 'the number or types of conditions which may be attached to national treatment commitments. A requirement that foreign banks wishing to establish in the country should set up branches in every village, for example, would also be perfectly legitimate' (WTO 2002b: 1).

However, ambiguities of interpretation and uncertainty in the agreement still remain. Take, for example, issues around technical standards and domestic regulation. Technical standards associated with formal network provision may need to be redesigned to facilitate network expansions to poor areas. The extent to which such a redefinition of technical standards would be possible under the GATS is not clear. Article VI.4 of the agreement requires current negotiations to develop regulatory disciplines, which can ensure that domestic 'qualification requirements and procedures, technical standards and licensing requirements do not constitute unnecessary barriers to trade in services' (WTO 1994: 290). Clearly, the outcome of these negotiations will depend on the exact definition of "technical standards" and "barriers to trade". There is still a lack of clarity on issues such as domestic laws, guidelines, subsidies, licensing standards and economic means tests. The GATS could also apply to all levels of governments (including federal and provincial). In India, for example, the state governments have relative autonomy in several sectors, including water, education, health and a broad application of the GATS could undermine the autonomy of provincial and local government. There is still no clarity on all these issues and the "Working Group on Domestic Regulation" has been charged with the development of these disciplines and their decisions will determine impacts on governments' freedom to act in a pro-poor fashion (see Mehta and la Cour 
Madsen 2003, for more details on technical standards and the equally controversial "necessity means test"). ${ }^{4}$

Furthermore, following the discussion in Section 3 , achieving universal provision of water services often requires explicit state involvement with respect to safety-net regulation. To fulfill this need for safety nets that guarantee access to water services for those who are unable to meet the costs associated with this, may imply that operators have to provide water free of charge to certain consumers (Finger and Allouche 2002). Private companies are, however, unlikely to perform this function without any reimbursement of costs and it is therefore essential that governments maintain the right to subsidise either suppliers or end consumers, when this is required to achieve legitimate social objectives. But the GATS currently contains no specific disciplines intended to govern the use of demand or supplyside subsidies and subsidisation is therefore only subject to the principle of non-discrimination in those cases where national treatment commitments have been made (McCulloch et al. 2001). We believe that it is essential that any future GATS disciplines developed in this area allow for the use of subsidies in cases where market failures make this the best instrument to legitimate social objectives. Still, following interviews with negotiators from middleincome and poor countries in Geneva is appears that the USA and the EU are not keen to flesh out and nuance the unfinished discussions of the Uruguay Round around the "rules dimension" concerning subsidies and safeguards that would protect the interests of the poor.

In sum, in an ideal world, the GATS does not appear to limit domestic governments' regulatory freedom of manoeuvre. However, the real world most typically falls short of being ideal and the possibility exists that the ambiguities around the interpretation of the agreement itself could be manipulated to serve the interests of powerful nations and corporations. Similarly, current GATS negotiations, especially on domestic regulation and subsidies, could result in inexpedient restrictions on governments' freedom to formulate and implement the regulation deemed necessary to safeguard the interests of the poor when private actors take part in the provision of water services.

\section{The politics of process}

Several aspects of the GATS negotiations have the potential to work against the realisation of the ideal scenario sketched out above. We call these realities of the politics of process. These refer to the unequal nature of members to participate equally in WTO processes and negotiations and the ways in which institutional arrangements at the WTO are embedded in wider issues of political economy and power. We focus on two key issues.

\subsection{Who has the capacity to regulate/negotiate?}

At the time of offering commitments, a government's ability to maintain a fair degree of regulatory freedom to oversee the liberalisation of its services under GATS depends on its ability to specify in the form of "limitations", any regulation that it would seek to maintain or develop. The specification of such "limitations" does, however, require an enormous degree of administrative capacity and foresight by GATS signatories at the point of making a commitment. Often this is lacking to many developing country negotiators. Consider this statement made by an ambassador from a poor country in an interview in June 2003:

Do we have the freedom to regulate? In principle yes. In reality no. The weaker country is usually at a massive disadvantage. In order to make a request or respond to one you need to give details of what exactly everything entails - you need to be familiar with national laws, rules and specific regulations, and that too for every country. We don't have this level of detail of other countries. By contrast, the more powerful countries have all these details about us ... this is reflected in their requests. I am astonished by the level of detail that they specify in their requests!

The ambassador was referring to the recent $\mathrm{EU}$ requests which were targeted at 109 countries, including all the countries classified as Least Developed Countries (LDC) in the WTO (World Development Movement 2003: 9). By contrast, the EU received requests from only one LDC (World Development Movement 2003: 12).

While it is true that the WTO secretariat has been offering promises of "technical assistance" and "capacity building" to developing countries, the actual assistance delivered is often very little more than the odd seminar presented by international WTO technocrats who are largely legal and economic 
specialists based in Geneva. Often they are not equipped to deal with intangible issues around social equity and participation, bearing in mind the local needs and concerns of local businesses, academics and civil society members. Rather than empowering developing countries to define, negotiate and consolidate their own positions vis-à-vis the WTO, there is a rather top-down approach towards assistance and capacity building which seeks to push countries to adapt to and take on board existing obligations and commitments, often framed by the Quad group (i.e. The European Union, the United States, Canada and Japan). Little wonder, then, that many developing country negotiators view activities around "capacity building" and "technical assistance" as a tool to pressurise developing countries to agree to negotiations on new issues (see also Jawara and Kwa 2003).

The request-offer mode often ends up being a bilateral negotiation between two countries, despite the multilateral context of the WTO. Clearly, the rich and powerful countries can exert tremendous pressure on a poorer country to respond quickly or positively to a request. Clearly there are many merits to multilateralism and the advantages that negotiating in Geneva offers. According to one LDC ambassador, "Here in Geneva the different developing countries can support each other and resist pressure. For example, the LDCs can get together and exert pressure or India, Brazil and South Africa can make noise. Back home in the capitals it's a different story. The process of armtwisting is much more overt' (interview with ambassador, Geneva, 19 June 2003). This is in keeping with research by Sheila Page who argues that despite uneven power relations in the negotiation process, developing countries have gradually improved their negotiating capacity from the experience gained through successive trade rounds and is developing sophisticated positions on a range of issues (Page 2003). However, the bilateral nature of the request-offer mode, coupled with pressure from other bilateral investment treaties arising from the Bank and IMF, can seriously undermine the slight advantages arising out of multilateral settings.

\subsection{No turning back?}

The potential negative consequences of governments' lack of capacity and foresight at the time of making GATS commitments seems to be reinforced by the rigidity of Article XXI of the GATS, which sets out the procedure that a country must follow in case it wants to modify its GATS commitments. The article specifies that (1) modifications cannot be initiated until three years after the initial commitment entered into force; (2) that other members must be given three months notice of what the nature of the modification is; and (3) that the modifying country must come up with compensating commitments, which compensate for the modification and satisfy all WTO members. As such, GATS commitments clearly take on a certain degree of irreversibility, if not in theory, then in practice and this could potentially have a negative effect on people's access to basic social services, among these water. This is particularly so if developing countries are pressured into making irreversible commitments before they fully understand the consequences.

Another issue related to the difficulties in reversing GATS commitments is rooted in the stated aim of the agreement, namely to 'progressively liberalise trade in services'. Since "progressive liberalisation" is to be achieved either through the commitment of more sectors or through the gradual elimination of existing barriers to trade in scheduled sectors, governments that have managed to make limitations to GATS provisions in their original schedules may be asked to give up such limitations by other GATS signatories in future negotiations. ${ }^{5}$ The fact that developing country negotiators are wary of the virtual irreversible nature of GATS may explain why they are making commitments to far fewer sectors than what has already taken place under processes of autonomous liberalisation in their countries. A negotiator from a middle-income country explains, 'We could get locked into a process which could just go badly wrong' (interview, 18 June 2003).

\section{Conclusion}

This article has argued that while the international liberalisation of basic social services under the GATS at the de jure level could be managed in ways that will be able to safeguard the interests of the poor, ambiguities in interpretation, power games, politics and reasons of a wider political economy suggest that GATS could de facto undermine poor people's rights to water. Taking into consideration the high level of natural monopoly, which characterises the water sector, and water's importance for human 
well-being, it is essential that domestic governments maintain the ability to regulate the water sector, if and when international liberalisation of water services becomes a reality. However, experiences from non-WTO-related water privatisation coupled with the lack of clarity around subsidies and domestic regulation around GATS leave us no real reason to be sanguine. And as we have demonstrated elsewhere (see Mehta and la Cour Madsen 2003), the present regime of the WTO/GATS also seems more comfortable with endorsing the rights of corporations than those of more marginalised constituencies. This coupled with the politics of WTO negotiations and processes often disadvantage weaker and poorer countries.

The collapse of talks at Cancun and the exit option pursued by developing countries there may signal the opportunity for actors in both the North and South to step back and reflect critically on what the various future negotiations (including the GATS) could mean for poor people's rights and well-being.

squarely in place, it is best that the social sectors such as water remain out of the reach of GATSdirected liberalisation.

\section{Notes}

* Research for this article took place within the scope of the DFID-funded research project 'Linking the WTO to the Poverty-Reduction Agenda'. We are grateful to all our interview partners in Geneva and the UK for their time and for sharing their knowledge with us. For obvious reasons, we have kept their views anonymous. We thank Rob Jenkins and John Humphrey for making this research possible and are grateful to them for their patience and very useful comments. The analysis presented here is developed further in Mehta and la Cour Madsen 2003. Responsibility for all errors that may remain rests solely with the authors.

1. For example, at the 2001 Bonn Freshwater Conference many stakeholders - including representatives of governments and business - made verbal endorsements of the human right to water, but the final conference doc-
In order for the GATS to be more consistent with social, equity and welfare concerns, there is an urgent need for adequate social, technical and economic assessments and more official attempts to mainstream human rights considerations. Systematic lessons need to be learnt from non-GATS privatisation experiences and options such as management contracts, which offer governments a greater say, should seriously be explored. There is also an urgent need for fairer and accountable systems around developing negotiating capacity that do not just promote the interests of the rich countries. Furthermore, the bilateral structure around the request/offer mode could shift to more genuine multilateral-style negotiations where developing countries are less disadvantaged. It is also necessary to abolish or amend the irreversibility provision, allowing for a flexible process whereby a country's commitments can be withdrawn if the economic, political and social changes that a country encounters demands this. Until these measures are

ument failed to acknowledge it explicitly.

2. Available at the World Meteorological Organisation website, www.wmo.ch/index-en.html (accessed November 2003).

3. Services provided in the exercise in governmental authority are defined as those supplied neither on a commercial basis nor in competition with other suppliers' (WTO 2002b: 1). The extent to which this implies that essential social services are not potentially subject to the GATS is widely debated. For a detailed discussion of this see Krajewski (2001).

4. Some of these criticisms of the potential negative impacts of the GATS are also endorsed by the High Commissioner for Human rights (HCHR) in several reports, which are the first step to determine the human rights impacts of trade; see United Nations Economic and Social Council (2002b).

5. For a relevant example of this around the Thai retail sector see World Development Movement 2003: 13-14. 


\section{References}

Bakker, K.J., 2002, 'From archipelago to network: urbanisation and water privatisation in the South', Working Paper Series No 02-05, Oxford: School of Geography and the Environment, University of Oxford, www.geog.ox.ac.uk/research/wpapers/ economic/wpg02-05.pdf (accessed July 2003)

Barr, N., 1998, The Economics of the Welfare State, 3rd edn, Oxford: Oxford University Press

Bayliss, K., 2001, Water Privatisation in Africa: Lessons from Three Case Studies, University of Greenwich: Public Services International Research Unit

Das, L.B., 2001, 'Restoring balance to services in WTO', Third World Network, www.twnside.org.sg/ (accessed October 2001)

Donnelly, J., 1999, 'Human rights, democracy and development', Human Rights Quarterly, Vol 21: 608-32

Finger, M. and Allouche, J., 2002, Water Privatisation: Trans-national Corporations and the Re-regulation of the Water Industry, London: Spon Press

GATSwatch, 2001, Stop the GATS Attack, www.gatswatch.org/StopGATS.html (accessed November 2001)

Jawara, F. and Kwa, A., 2003, Behind the Scenes at the WTO: The Real World of International Trade Negotiations, London: Zed Books

Kikeri, S., Nellis, J. and Shirley, M., 1994, 'Privatisation: lessons from market economies', World Bank Research Observer, Vol 9 No 2: 241-72

Krajewski, M., 2002, 'Public interests, private rights and the "constitution" of GATS', mimeo, Warwick: Centre for the Study of Globalisation and Regionalisation, University of Warwick

Krajewski, M., 2001, 'Public services and the scope of the General Agreement on Trade in Services', Centre for International Environment Law (CIEL) Research Paper, Washington, DC, w W W . g a $\mathrm{t}$ s watch.org/GATSandDemocracy/public.html (accessed July 2003)

Loftus, A. and McDonald, D., 2001, 'Lessons from Argentina. The Buenos Aires water concession', Municipal Services Project. Occasional Papers Series 2, Ontario, Canada

McCulloch, N., Winters, L.A. and Cirera, X.,
2001, Trade Liberalisation and Poverty: A Handbook, London: Department for International Development

Mehta, L., 2003, 'Problems of Publicness and Access Rights: Perspectives from the Water Domain', in I. Kaul, P. Conceicao, K. le Goulven and R. Mendonza (eds), Providing Global Public Goods. Managing Globalization, New York: Oxford University Press

Mehta, L. and la Cour Madsen, B., 2003, 'Is the WTO after your water? The General Agreement on Trade and Services (GATS) and the basic right to water', paper prepared for the research project on Linking the WTO to the Poverty-Reduction

Agenda, www.gapresearch.org/Mehta-Water-WEBAug03.pdf (accessed August 2003)

Neto, F. and Tropp, H., 2000, 'Water supply and sanitation services for all: global progress during the 1990s', Natural Resources Forum, Vol 24 No 3: 225-35

Nickson, A., 2001, 'Tapping the market. Can private enterprise supply water to the poor?', Insights 37, Brighton: Institute of Development Studies

Page, S., 2003, 'Developing countries: victims or participants. Their changing role in international negotiations', ODI Briefing Paper, London: Overseas Development Institute, www.gapresearch.org/ governance/participation.html (accessed October 2003)

Petrella, R., 2001, The Water Manifesto: Arguments for a World Water Contract, London: Zed Books

Rees, J.A., 1998, 'Regulation and private participation in the water and sanitation sector', TAC Background Paper 1, Global Water Partnership Technical Advisory Committee, www.cepis.ops-oms.org/bvsarg/i/fulltext/tacl/ tacl.pdf (accessed July 2003)

Rivera, D., 1996, 'Private sector participation in water supply and sanitation: lessons from six developing countries', World Bank Directions in Development, Washington, DC: World Bank

Ugaz, C., 2001a, 'Privatisation of utilities and the universal right to basic services', mimeo, The United Nations University, Helsinki: World Institute for Development Economics Research (WIDER)

Ugaz, C., 2001b, 'A public goods approach to 
regulation of utilities', Discussion Paper 2001/9, Helsinki: United Nations University, World Institute for Development Economics Research (WIDER)

United Nations Economic and Social Council, 2002a, 'Substantive issues arising in the implementation of the international covenant on economic, social and cultural rights' Committee on Economic, Social and Cultural Rights, General Comment 15, E/C.12/2002/11, www.unhchr.ch (accessed June 2003)

United Nations Economic and Social Council, 2002b, 'Liberalisation of trade in services and human rights', Commission on Human Rights, Subcommission on the Promotion and Protection of Human Rights Report of the High Commissioner, 25 June 2002: E/CN.4/Sub.2/2002/9, www.unhchr.ch (accessed June 2003)
World Bank, 1994, 'Infrastructure for development', World Development Report 1994, New York: Oxford University Press

World Development Movement, 2003, Whose Development Agenda? An Analysis of the European Union's GATS Requests of Developing Countries, London: World Development Movement

World Development Movement, 2002, GATS: A Disservice to the Poor, London: World Development Movement

WTO, 2002a, Communication from Cuba, Dominican Republic, Kenya, Nigeria, Pakistan, Senegal and Zambia: Assessment of Trade in Services, TN/S/W/310, Geneva: World Trade Organization WTO, 2002b, 'GATS - fact and fiction', World Trade Negotiation, Geneva: World Trade Organization, http://wto.org/English/ tratop_e/serv_e/ gats_factfiction_e.html (accessed October 2002) WTO, 1998, 'Disciplines on domestic regulation 